\title{
NEW RECORDS OF THE MOLLUSK Firoloida desmarestia LESUEUR, 1817 (GASTROPODA: PTEROTRACHEIDAE) OFF FERNANDO DE NORONHA ARCHIPELAGO AND NORTHEASTERN BRAZILIAN CONTINENTAL SLOPE, TROPICAL ATLANTIC
}

\author{
Gabriela Guerra Araújo Abrantes de FIGUEIREDO1*; Ralf SCHWAMBORN1; Arnaud BERTRAND²; \\ Simone Maria Albuquerque LIRA $^{1,3}$
}

\begin{abstract}
${ }_{1}^{1}$ Department of Oceanography, Federal University of Pernambuco, Recife, Brazil. Av. Arquitetura, $\mathrm{s} / \mathrm{n}$ Cidade Universitária, 50740-550 Recife, PE, Brazil. E-mail: gabriela.gaaf@gmail.com, ralf.schwamborn@ufpe.br

*Corresponding author
\end{abstract}

2Institut de Recherche pour le Développement (IRD), MARBEC, Université de Montpellier, CNRS, Ifremer, IRD, Sète, France. E-mail: arnaud.bertrand@ird.fr

${ }^{3}$ Department of Biology, Federal Rural University of Pernambuco, Recife, Brazil. E-mail: simonealira@gmail.com

\begin{abstract}
RESUMO.
O conhecimento biogeográfico e taxonômico sobre moluscos planctônicos, especificamente sobre Pterotracheoidea (também conhecidos como heterópodes ou elefantes marinhos) nos oceanos tropicais, ainda está incompleto. Neste artigo relatamos o primeiro registro da heteropoda Firoloida desmarestia Lesueur (1817) sobre as águas da encosta continental do Nordeste brasileiro e do Arquipélago de Fernando de Noronha e ampliamos sua distribuição geográfica no Atlântico tropical. Fornecemos nova imagem digital detalhada e descrições desta espécie gelatinosa altamente frágil e transparente. As amostras foram coletadas no contexto do projeto 'ABRACOS' (Acústica ao longo da costa brasileira) usando redes de bongo. Das 96 amostras analisadas, seis exemplares foram registrados em cinco amostras, três em Fernando de Noronha e três na costa nordeste do Brasil. O presente estudo estende a distribuição de $F$. desmarestia a $3^{\circ} \mathrm{S}-9^{\circ} \mathrm{S}$ no oeste do Atlântico Tropical e destaca a importância de estudos detalhados sobre a biodiversidade de plâncton gelatinoso de grande porte nos oceanos tropicais.
\end{abstract}

Palavras-Chave: Ilhas oceânicas tropicais, talude continental, zooplâncton, heterópodes, Pterotracheidae

\begin{abstract}
Biogeographic and taxonomic knowledge on planktonic mollusks, specifically on Pterotracheoidea (also known as heteropods or sea elephants) in tropical oceans, is still incomplete. In this paper we report the first record of the heteropod Firoloida desmarestia Lesueur (1817) on waters off the Northeast Brazilian continental slope and Fernando de Noronha Archipelago and extend its geographic distribution in the tropical Atlantic. We provide new detailed digital image and descriptions of this highly fragile and transparent gelatinous species. Samples were taken in the context of the 'ABRACOS' (Acoustic along the Brazilian Coast) project using bongo nets. Out of 96 samples analyzed, six specimens were recorded in five samples, three at Fernando de Noronha, and three off the Northeast Brazilian coast. The present study extends the range of distribution of $F$. desmarestia to $3^{\circ} \mathrm{S}-9^{\circ} \mathrm{Sin}$ the western the Tropical Atlantic and highlights the importance of detailed studies on large-sized gelatinous plankton biodiversity in tropical oceans.
\end{abstract}

Keywords: Tropical oceanic islands, Continental slope, zooplankton, heteropods, Pterotracheidae. 
Figueiredo et al., New records of the mollusk Firoloida desmarestia Lesueur, 1817 (Gastropoda: Pterotracheidae) off Fernando de Noronha Archipelago and Northeastern Brazilian continental slope, Tropical Atlantic.

\section{INTRODUCTION}

The gastropod superfamily Pterotracheoidea, also known as heteropods or 'sea elephants', comprises about 250 species of fragile holoplanktonic mollusks, with a worldwide geographic distribution in tropical and subtropical oceans (Moreno-Alcántara et al., 2014). One group of heteropods with very little data on their distribution is a monotypic genus represented only by Firoloida desmarestia Lesueur, 1817 (Gastropoda: Pterotracheidae). It is a naked pelagic heteropod with a completely transparent soft body (Lesueur, 1817). As all heteropods, F. desmarestia swims by movements of a single swimming fin. Furthermore, they have welldeveloped eyes, an indication of a visual predator (Land, 1982), with the main food source being gelatinous zooplankton (Lalli and Gilmer, 1989). The main predators of $F$. desmarestia are other heteropod species, fish, and large zooplankton, such as siphonophores, medusae and phyllosoma larvae (Lalli and Gilmer, 1989; Wang et al., 2014).

This species occurs tipically at tropical and subtropical latitudes (Seapy et al., 2003). These organisms were observed, among other, in the Gulf of California (Angullo-Capillo, 2010), in the Central Pacific (Seapy, 1990), off Chile (Pagès et al., 2001). In the Atlantic, this species was found by Tesch (1949), Northern, Western Atlantic, Atlanto-Mediterranean faunistic centers by Van der Spoel (1976) and Gulf of Mexico by Lemus-Santana et al. (2015). Moreover, Vannucci (1951) recorded F. desmarestia from Trindade Island, Brazil, and recently, Burridge et al. (2017) recorded $F$. desmarestia along a meridional transect through the Atlantic. Along the Northeastern Brazilian waters, some studies addressed the spatial distribution and taxonomic diversity of planktonic mollusks (e.g., Koblitz and Larrazábal, 2014; Larrazábal and Oliveira, 2003) and reported more than 20 species of planktonic gastropods. However, none of them recorded the presence of $F$. desmarestia. In this study, we provide new records of $F$. desmarestia off the northeast Brazilian coast (continental slope) and the oceanic archipelago of Fernando de Noronha, Brazilian Province, providing detailed diagnoses and digital image of this species.

\section{MATERIAL AND METHODS}

Zooplankton samples were collected during the 'ABRACOS 2' (Acoustic along the Brazilian Coast, Bertrand, 2017) survey conducted on board R/V ANTEA off the Northeastern Brazilian continental slope waters (open areas) and oceanic islands in April 2017 (Fig. 1). A total of 96 zooplankton samples were collected using bongo net trawls $(2 \times 60 \mathrm{~cm}$ diameter, mesh sizes of 300 and $500 \mu \mathrm{m})$. Oblique tows were conducted between $200 \mathrm{~m}$ and the surface in oceanic areas and from the bottom to the surface in neritic waters. All samples were preserved in $4 \%$ formaldehyde buffered with sodium tetraborate $\left(0.5 \mathrm{gl}^{-1}\right.$, Newell and Newell, 1963). 
Figueiredo et al., New records of the mollusk Firoloida desmarestia Lesueur, 1817 (Gastropoda: Pterotracheidae) off Fernando de Noronha Archipelago and Northeastern Brazilian continental slope, Tropical Atlantic.

In the laboratory, subsamples ( $1 / 2$ to $1 / 64)$ obtained using a zooplankton Motoda splitter (up to 2,000 organisms) were analyzed and $F$. desmarestia specimens were identified according to Lesueur (1817), Seapy (2008) and Lemus-Santana et al. (2015). One organism was stained with $2 \%$ acetic carmine (Silva, K. unpublished results) and was used for detailed descriptions and digital images, using a Zeiss Axio Scope A1 with Zen software and later treated in Adobe Photoshop CS6. For the visualization of these fragile and transparent organisms, multi-focal images were acquired and combined using the Zen Blue 2011 (Zeiss) software.

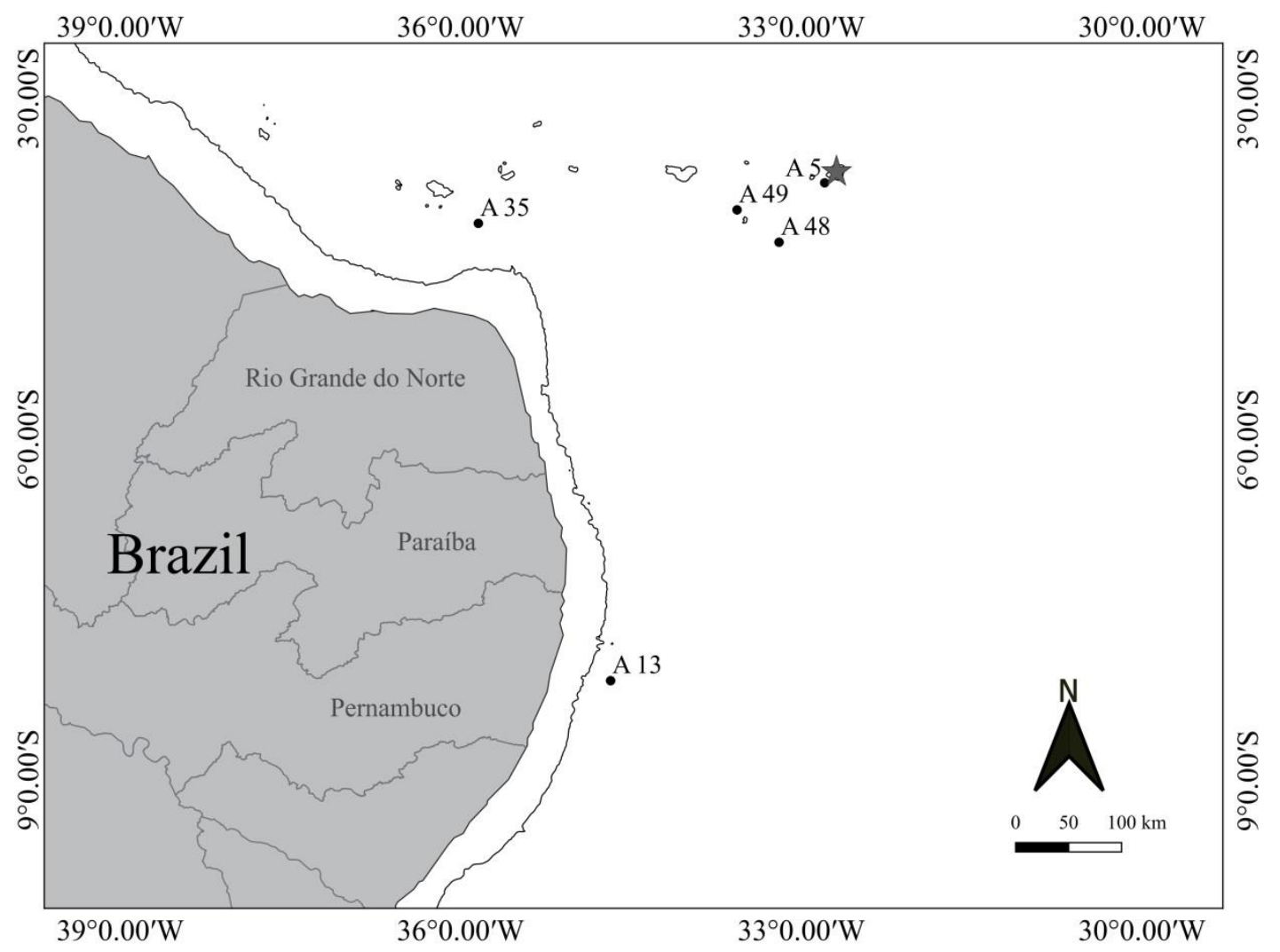

Figure 1. Map of the study area in the western tropical Atlantic showing the sampling stations with occurrence of Firoloida desmarestia. Continuous line: $200 \mathrm{~m}$ isobath. Gray star: Fernando de Noronha archipelago).

\section{RESULTS AND DISCUSSION}

Planktonic gastropods were found in all 96 samples analyzed. Firoloida desmarestia was represented by six specimens found at five stations (Fig. 1) i.e, $4 \%$ of samples. Over the continental slope, three specimens were recorded during nighttime (Fig 2; Tab. 1). Off Fernando de Noronha (Fig. 2; Tab. 1), three specimens were caught, during daytime and nighttime. 
Figueiredo et al., New records of the mollusk Firoloida desmarestia Lesueur, 1817 (Gastropoda: Pterotracheidae) off Fernando de Noronha Archipelago and Northeastern Brazilian continental slope, Tropical Atlantic.

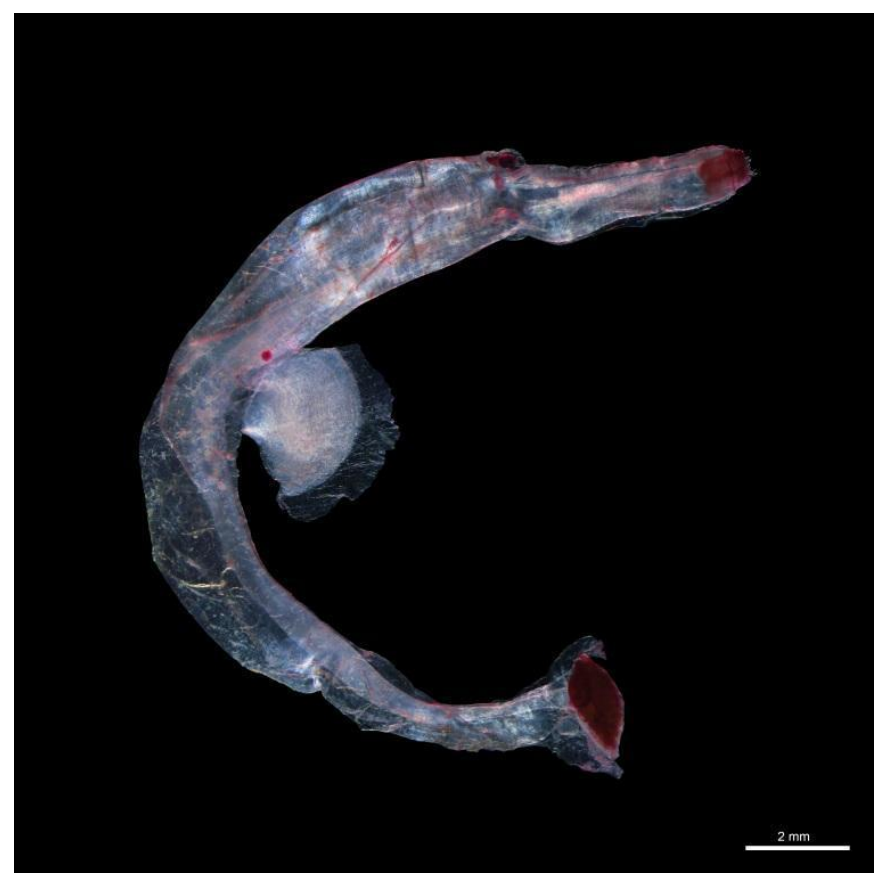

Figure 2. Firoloida desmarestia Lesuer (1817) sampled off Fernando de Noronha Archipelago, Brazil.

Table 1. Sampling station, geographic coordinates, sampling station (FN: Fernando de Noronha), abundance, gear and mesh size used to collect Firoloida desmarestia.

\begin{tabular}{ccccccc}
\hline Station & Latitude $(\mathrm{S})$ & Longitude $(\mathrm{W})$ & Local & Date & Time & Mesh $(\mu \mathrm{m})$ \\
\hline 5 & -9.136 & -34.753 & FN & $10 / 04 / 2017$ & $23: 56$ & 300 \\
13 & -8.323 & -34.402 & Slope & $13 / 04 / 2017$ & $19: 47$ & 500 \\
35 & -4.297 & -35.567 & Slope & $21 / 04 / 2017$ & $00: 29$ & 300 \\
$48 *$ & -4.463 & -32.918 & FN & $30 / 04 / 2017$ & $13: 22$ & 500 \\
48 & -4.463 & -32.918 & FN & $30 / 04 / 2017$ & $13: 22$ & 500 \\
49 & -4.178 & -33.288 & FN & $01 / 05 / 2017$ & $00: 46$ & 500 \\
\hline
\end{tabular}

*: Photographed specimens

\section{SYSTEMATICS}

Phylum Mollusca

Class Gastropoda Cuvier, 1795

Subclass Caenogastropoda

Order Littorinimorpha

Superfamily Pterotracheoidea

Family Pterotracheidae

Genus Firoloida Lesueur, 1817

Species Firoloida desmarestia Lesueur, 1817 
Figueiredo et al., New records of the mollusk Firoloida desmarestia Lesueur, 1817 (Gastropoda: Pterotracheidae) off Fernando de Noronha Archipelago and Northeastern Brazilian continental slope, Tropical Atlantic.

MATERIAL EXAMINED. Brazil, Northeast Brazilian open area waters and oceanic islands, "ABRACOS 2 survey", bongo net, 300 and $500 \mu \mathrm{m}$ mesh sizes.

\section{Firoloida desmarestia MORPHOLOGICAL CHARACTERISTICS}

A transparent elongate cylindrical body with a long trunk and short tail, a terminal visceral nucleus on the trunk, a swimming fin anterior of the middle part of the trunk (sense Lesueur, 1817). They are gonochoristic and have sexual dimorphism in which the males have a large penis, a tentacle aside each eye, a sucker on the swimming fin and a rudimentary tail. The females lack a tail, they own a permanent egg string that extends posteriorly from the base of the visceral nucleus (Lemus-Santana et al., 2015). The eyes are narrowly triangular; large and oblong lens capsule with basal and distal portion slightly opaque. Little is known about the maturity of females. According to Tesch (1949) the maturity is not strictly dependent of the size of individuals once he observed egg strings in female organisms ranging from $10-40 \mathrm{~mm}$ in length.

\section{REMARKS}

This study provides the first record of $F$. desmarestia, a planktonic mollusk for Fernando de Noronha Archipelago and above the continental slope (open areas) off Northeast Brazil and extends its distribution between $3^{\circ} \mathrm{S}-9^{\circ} \mathrm{S}$ in the western Tropical Atlantic. Its absence in previous studies in the regions probably due several factors, for example the fact that these organisms are very fragile (often destroyed during plankton hauls), as well as the fact that this species was never the focus of the studies. In this study, this species showed extremely low abundance ( 1 to 2 ind. per sample) and frequency of occurrence (present in $4 \%$ of samples). Being several millimeters long, F. desmarestia was among the largest organisms in the plankton community sampled in this study. Large-sized predators are key elements of marine food webs (Gusmão et al., 2014), which may have been underrepresented in many previous plankton surveys.

We mostly captured $F$. desmarestia at nighttime (four organisms at night, and two organisms during the day). These organisms, like most of gelatinous plankton, probably perform diel vertical migrations, rising from deeper depths and being captured in shallower waters at night. Although F. desmarestia occurs depths down to 150 meters (Seapy, 1990; Seapy, 2008), new studies with other types of nets and at greater depths are necessary to improve the knowledge on their distribution, abundance and other ecological aspects. Around Fernando de Noronha Archipelago, for example, a large biomass of gelatinous was observed by acoustic with part of the community performing consistent diel vertical migrations (Vargas et al., 2017). Their study highlights the importance of large-sized gelatinous organisms (e.g., hydromedusae, salps, chaetognaths, and planktonic gastropods) that are also underestimated prey for the mesopelagic community (Eduardo et al., 2020). 
Figueiredo et al., New records of the mollusk Firoloida desmarestia Lesueur, 1817 (Gastropoda: Pterotracheidae) off Fernando de Noronha Archipelago and Northeastern Brazilian continental slope, Tropical Atlantic.

This study contributes to the knowledge of the planktonic fauna of the tropical Atlantic, and may provide useful information to diversity in marine protected areas off oceanic islands (Fernando de Noronha Archipelago). The plankton biodiversity in waters off these isolated insular environments should be studied more intensively, since they play invaluable biogeographic and ecological roles in the tropical Atlantic (e.g., as stepping-stones between Africa and South America) (Lira et al., 2017), contributing to the dispersal and continuity of these and many other species. The other region (station 35) where $F$. desmarestia was recorded, around the Ceará seamounts, is also characterized by a lack of study.

A combined use of different sampling methods (e.g., Bongo nets, MOCNESS, openingclosing nets), will probably be necessary for an efficient capture of this species, with high potential to reveal new records of planktonic taxa in tropical oceanic waters. Lemus-Santana et al. (2015) used an opening-closing net and captured around 350 specimens of $F$. desmarestia in the slope region and on the narrow part of shelf of the Gulf of Mexico, evidencing their oceanic origin. They also observed that adults specimens were found in upper levels $(0-18 \mathrm{~m})$ and young specimens were mainly found between 45 and $105 \mathrm{~m}$. In the future, more specific sampling campaigns may yield high numbers of these little investigated gelatinous predators in many other areas.

This study highlights the importance of detailed taxonomic studies with plankton samples, ideally to be analyzed in toto, to better quantify the rare species. Moreover, the present study extends the occurrence of $F$. desmarestia between $3^{\circ} \mathrm{S}-9^{\circ} \mathrm{S}$ in the western Tropical Atlantic.

\section{ACKNOWLEDGEMENTS}

We would like to thank the National Council for Scientific and Technological Development (CNPq, PhD fellowships awarded to the first author), the ABRACOS project (Acoustics along the Brazilian Coast, funded by Flotte Oceanographique Française), the crew of R/V ANTEA, the Brazilian National Institute of Science and Technology in Tropical Marine Environments (INCTAmbTropic, CNPQ/CAPES/FAPESB) for the logistic and financial support; the Coordenação de Aperfeiçoamento de Pessoal de Nível Superior (CAPES/PORAP no 206, September, 4, 2018) This work is a contribution to the LMI TAPIOCA. RS and $A B$ received support from the European Union's Horizon 2020 research and innovation program under Grant Agreement No 734271. Many thanks to Kaio Farias for the photo of Firoloida desmarestia.

\section{REFERENCES}

Angulo-Campillo, O., Aceves-Medina, G. and Avedaño-Ibarra, R. (2011), Holoplanktonic mollusks (Mollusca: Gastropoda) from the Gulf of California, México, CheckList: Journal of species lists and distribution, Vol. 7, pp. 337-342. https://doi.org/10.15560/7.3.337 
Figueiredo et al., New records of the mollusk Firoloida desmarestia Lesueur, 1817 (Gastropoda: Pterotracheidae) off Fernando de Noronha Archipelago and Northeastern Brazilian continental slope, Tropical Atlantic.

Bertrand, A. (2017), ABRACOS 2 cruise, RV Antea, https://doi.org/10.17600/17004100.

Burridge, A.K., Goetze, E., Wall-Palmer, D., Le Double, S.L., Huisman, J., and Peijnenburg, K.T. (2017), Diversity and abundance of pteropods and heteropods along a latitudinal gradient across the Atlantic Ocean, Progress in Oceanography, Vol. 158, pp. 213-223. https://doi.org/10.1016/j.pocean.2016.10.001.

Eduardo, L.N., Bertrand, A., Mincarone, M.M., Silva, L.V.S., Frédou, T., Assunção, R., Silva, A., Ménard, F., Schwamborn, R., Le Loch, F. and Lucena-Frédou, F. (2020), Hatchet fishes (Stomiiformes: Sternoptychidae) biodiversity, trophic ecology, vertical niche partitioning and functional roles in the western Tropical Atlantic, Progress in Oceanography, Vol. 185, p. 102389 . DOI: $10.1016 /$ j.pocean.2020.102389.

Gusmão, L.M.O., Diaz, X.F.G., de Melo Jr, M., Schwamborn, R. and Neumann-Leitão, S. (2014), Jellyfish diversity and distribution patterns in the tropical Southwestern Atlantic, Marine Ecology, Vol. 36, pp. 93-103. https://doi.org/10.1111/maec.12119

Koblitz, V., S., and Larrazábal, M., E., L. (2014), Characterization of the geographic distribution pattern of the family Limacinidae Gray, 1840 (Mollusca Gastropoda) in the waters of Northeastern of Brazil. Biota Neotropica, Vol. 14, pp. 1-15. DOI https://doi.org/10.1590/1676-06032014002913

Lalli C., M., Gilmer R., W. (1989), Pelagic snails: the biology of holoplanktonic gastropod mollusks. Stanford University Press, Stanford

Land M. F. (1982), Scanning eye movements in a heteropod mollusk. J Exp Biol, Vol. 96, pp. $427-430$

Larrazábal, M.E.D., \& Oliveira, V.S.D. (2003), Thecosomata e Gymnosomata (Mollusca, Gastropoda) da cadeia Fernando de Noronha, Brasil. Revista Brasileira de Zoologia, Vol. 20, pp. 351-360. https://doi.org/10.1590/S0101-81752003000200028

Lemus-Santana, E., Sanvicente-Añorve, L., Alatorre-Mendieta, M. and Flores-Coto, C. (2015), Population structure and mating encounter rates in a marine pelagic invertebrate Firoloida desmarestia (Mollusca). Sexuality and Early Development, Aquatic Organisms, Vol. 1, n. 2, pp. 163-173. https://doi.org/10.3354/sedao00015

Lesueur, C.A. (1817), Characters of a new genus, and descriptions of three new species upon which it is formed; discovered in the Atlantic ocean, in the months of March and April, 1816; Lat. 229', Journal of the Academy of Natural Sciences, Vol. 1, pp. 37-41.

Lira, S.M.A., Santana, C.S., Lima, C.D., Montes, M.J. and Schwamborn, R. (2017), New records of the larval forms Cerataspis monstrosa and Amphionides reynaudii (Crustacea: Decapoda) from the western tropical Atlantic, Zootaxa, Vol. 4237, pp. 335-346. https://doi.org/10.11646/zootaxa.4237.2.7 
Figueiredo et al., New records of the mollusk Firoloida desmarestia Lesueur, 1817 (Gastropoda: Pterotracheidae) off Fernando de Noronha Archipelago and Northeastern Brazilian continental slope, Tropical Atlantic.

Lira, S.M.A., Santana, C.S. and Schwamborn, R. (2018), First record of Naushonia sp. (Decapoda: Laomediidae) larva from the Equatorial Atlantic, Zootaxa, Vol. 4387, pp. 183194. https://doi.org/10.11646/zootaxa.4387.1.9

Moreno-Alcántara M., Aceves-Medina G., Angulo-Campillo O., Murad-Serrano J. (2014), Holoplanktonic molluscs (Gastropoda: Pterotracheoidea, Thecosomata and Gymnosomata) from the southern Mexican Pacific. Journal of Molluscan Studies, Vol. 80, pp. 131-138. https://doi.org/10.1093/mollus/eyu006

Newell, G., E. and Newell, R., C. (1963), Marine plankton: a practical guide. London: Hutchlson Educational

Pagès, F., González, H.E., Ramón, M., Sobarzo, M. and Gili, J.M. (2001), Gelatinous zooplankton assemblages associated with water masses in the Humboldt Current System and potential predatory impact by Bassiabassensis (Siphonophora: Calycophorae), Marine Ecology Progress Series, Vol. 210, pp. 13-24. https://doi.org/10.3354/meps210013.

Seapy, R.R. (1990), Patterns of vertical distribution in epipelagic heteropod mollusks off Hawaii, Marine Ecology Progress Series, Vol. 60, pp. 235-246. https://doi.org/10.3354/meps060235.

Seapy, R.R. (2008), Offshore-inshore and vertical distributional patterns of heteropod mollusks off leeward Oahu, Hawaii, Marine Biology, Vol. 154, pp. 985-995. https://doi.org/10.1007/s00227-008-0989-9

Seapy, R.R., Lalli, C.M. and Wells, F.E. (2003), Heteropoda from Western Australia waters, in Wells, F.E., Walker, D.I. and Jones, D.S. (Eds), The Marine Flora and Fauna of Dampier, Western Australia, Western Australian Museum, Perth, pp. 513-546.

Tesch, J.J. (1949), Heteropoda. The Carlsberg Foundation's Oceanographical Expedition round the world 1928-30 and previous 'Dana' expeditions, Dana Report No. 34, Bianco Luno A/S, Copenhagen.

Van der Spoel, S. (1976), Pseudothecosomata, Gymnosomata and Heteropoda (Gastropoda), Utrecht: Bohn, Scheltema \& Holkema, 484p.

Vannucci, M. (1951), Resultados científicos do cruzeiro do "Baependi" e do "Vega" à Ilha da Trindade: o gênero Firoloida, Prosobranchia Heteropoda, Boletim do Instituto Paulista de Oceanografia, Vol. 2, n. 2, pp. 73-93. https://doi.org/10.1590/S010042391951000200004.

Vargas, G., Lucena-Frédou, F., Habasque, J., Lebourges-Dhaussy, A., Roudaut, G. and Bertrand, A. (2017), A new multi frequency acoustic method for the discrimination of biotic components in pelagic ecosystems: Application in a high diversity tropical ecosystem 
Figueiredo et al., New records of the mollusk Firoloida desmarestia Lesueur, 1817 (Gastropoda: Pterotracheidae) off Fernando de Noronha Archipelago and Northeastern Brazilian continental slope, Tropical Atlantic.

off Northeast Brazil, IEEE/OES Acoustics in Underwater Geosciences Symposium (RIO Acoustics), pp. 1-8. DOI: 10.1109/RIOAcoustics.2017.8349719.

Wang, M., O'Rorke, R., Nodder, S., D., and Jeffs, A., G. (2014), Nutritional composition of potential zooplankton prey of the spiny lobster phyllosoma (Jasus edwardsii). Marine and Freshwater Research, Vol. 65, n. 2, pp. 337-349. https://doi.org/10.1071/MF13048 